
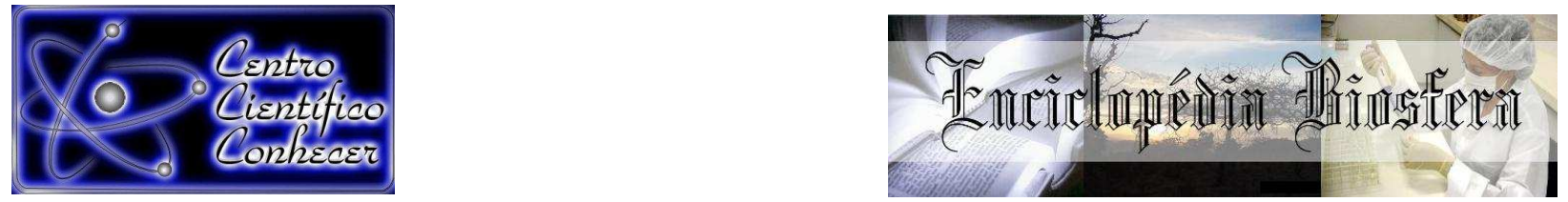

\title{
USO E APROPRIAÇÃO DO CERRADO GOIANO: UMA LEITURA SOBRE OS EFEITOS SOCIOESPACIAIS DA TERRITORIALIZAÇÃO DO AGRONEGÓCIO CANAVIEIRO NA MICRORREGIÃO DE CERES - GO
}

Jéssyca Tomaz de Carvalho

Graduada em Geografia- Programa de Pós-Graduação em Geografia (PPGeo) Instituto de Estudos Socioambientais (IESA) Universidade Federal de Goiás (UFG).Jessyca_tc_@hotmail.com, Goiânia - Goiás - Brasil

Recebido em: 08/04/2017 - Aprovado em: 10/06/2017 - Publicado em: 20/06/2017 DOI: 10.18677/EnciBio_2017A142

\begin{abstract}
RESUMO
O processo de uso e apropriação do Cerrado intensificou-se, sobretudo, na década de 1970 com a modernização conservadora da agricultura e a chamada Revolução Verde. Os efeitos dessa ocupação incentivada pelo Estado demandam ser investigados à medida que o projeto hegemônico instalado nesse espaço concentra o lucro (obtido a qualquer custo) e divide os prejuízos com a sociedade. O objetivo do presente estudo, para tanto, foi investigar esses efeitos de uma das faces do agronegócio sobre o Cerrado, tendo como recorte a microrregião de Ceres. Para tanto, foram realizadas: revisão bibliográfica, visitas de campo, levantamento de dados em fontes secundárias, bem como considerou-se para a elaboração desse artigo reflexões acerca do tema, pautadas em disciplinas e eventos. Notou-se, com o estudo, a expansão da produção canavieira na microrregião e que entre tantos efeitos, o desmatamento, a disputa hídrica, o desequilíbrio ecológico, a poluição, o comprometimento de outros cultivos, a reconfiguração territorial e o cercamento camponês apresentam-se como os efeitos socioambientais que mais incomodam a população. A ausência de fiscalização foi identificada como um dos principais problemas, sendo necessário pensar políticas públicas eficazes no intuito de contribuir para a $(R e)$ Existência de outros modelos de produção agrícola, que valorizem a justiça social no Cerrado.
\end{abstract}

PALAVRAS-CHAVE: Agronegócio; Cerrado; Efeitos socioambentais.

\section{USE AND APPROPRIATION OF CERRADO GOIANO: A READING ABOUT THE SOCIO-SPATIAL EFFECTS OF TERRITORIALISATION OF THE SUGARCANE AGRIBUSINESS IN THE CERES - GO MICRO REGION}

\begin{abstract}
The process of Cerrado use and appropriation intensifies, especially in the 1970 with the conservative modernization of agriculture and the Green Revolution. The effects of this occupation encouraged by the state demand to be investigated as the hegemonic project installed in this space focuses profit (obtained at any cost) and divides the losses to society. The purpose of this study, therefore, was to investigate
\end{abstract}


these effects of one of the faces of agribusiness on the Cerrado, of Ceres-GO. Therefore, there were literature review, field visits, data collection on secondary sources and was considered for the preparation of this article reflections on the subject, guided in disciplines and events. Is noted with the study, an increasing expansion of sugarcane production in the micro-region and among many effects, deforestation, water dispute, the ecological imbalance, pollution, impairment of other crops, the territorial reconfiguration and the peasant fencing feature themselves as the social and environmental effects that most annoy the population. The lack of oversight has been identified as a major problem, it is necessary to think of effective public policies in order to contribute to the $(R e)$ Existência of other models of agricultural production, that value social justice.

KEYWORDS: Agribusiness; Cerrado; socioambentais effects.

\section{INTRODUÇÃO}

Para construção deste artigo buscou-se uma abordagem integrada sobre o Cerrado; entendendo Cerrado não pela restrita noção de fitofisionomia, mas sim uma compreensão que extrapola os aspectos naturais e não se limita a interpretação do bioma. Buscou-se então estabelecer uma abordagem territorial do Cerrado. A proposta de uma abordagem territorial vem sendo desenvolvida por pesquisadores do Instituto de Estudos Socioambientais da Universidade Federal de Goiás já há alguns anos. O livro: Cerrados, perspectivas e olhares, organizado por PELÁ \& CASTILHO (2010) evidencia essa leitura. Conforme explicam os autores, do ponto de vista metodológico, faz-se necessário "um diálogo com diferentes abordagens para situar a análise do Cerrado como um território em disputa" (CHAVEIRO \& CASTILHO, 2010).

Para BORGES (2006) a apropriação do Cerrado é marcada por fatores exógenos, como as mudanças do processo produtivo com a industrialização do campo como padrão industrial, as técnicas e ciência incorporadas ao território, a fluidez do território e as guerras fiscais e dos lugares, a expansão dos investimentos para o interior brasileiro, a construção de marcos urbanos no Cerrado e as políticas públicas de incentivo e os fatores endógenos, como os recursos da natureza, a atividade agropecuária, as políticas e ações regionais de atração de investimentos e as amenidades do mundo do trabalho, que marcaram/marcam o processo de apropriação do Cerrado

A proposta deste artigo, portanto, é ampliar a leitura sobre a territorialização do agronegócio no Cerrado Goiano, com o objetivo de identificar os principais efeitos socioespaciais da territorialização do agronegócio canavieiro na microrregião (MRG) Ceres-GO, especialmente a partir da implantação do Plano Nacional de Agroenergia (PNA), enquanto recorte temporal para análise. Para delinear-se 0 objetivo apresentado e para que o mesmo fosse elucidado, destaca-se a colaboração de algumas informações obtidas em atividades de campo da pesquisa de dissertação de mestrado da autora - em desenvolvimento, a qual aborda tema similar. $O$ levantamento de dados quantitativos de fontes secundárias, com o intuito de complementar as informações levantadas em fontes orais; e ponderações e debates levantados sobre o tema em eventos e disciplinas também foram considerados. 


\section{O projeto hegemônico e a apropriação do Cerrado}

Identificar a expansão do capitalismo sobre o território é fundamental para a compreensão do processo de apropriação do Cerrado. Ao tomar-se como abordagem o território nacional é necessário compreendê-lo como um produto da história, conforme explica ARRAIS (2013). Isso possibilita dimensionar os problemas da questão agrária, mal equacionados desde o período colonial que implicam em efeitos socioespaciais ainda hoje. $\mathrm{O}$ autor elucida também que, é imprescindível a leitura sobre o papel do Estado, ao buscar-se compreender esse processo de uso e apropriação do espaço, sendo necessário entender o Estado pelas contradições e conflitos próprios do capitalismo e lidando com a produção de territórios desiguais.

A apropriação do Cerrado trata-se, portanto, de um processo que inicia-se pela ocupação que se deu por diferentes vias e interesses, imersos nessas contradições. Em uma breve proposta de periodização, pode-se remontar esse processo com alguns marcos temporais, como sugerido por CHAVEIRO \& CASTILHO (2010), destacando ainda a exploração aurífera do Brasil Colonial, a ocupação do sul pelos geralistas a partir do século XIX, a estrada de ferro a partir da segunda década do século XX, a Marcha para o Oeste, com a criação da CANG e a expansão da fronteira agrícola a partir da década de 1970.

A expansão da fronteira agrícola foi impulsionada pela modernização conservadora da agricultura (GRAZIANO NETO, 1982) e a chamada Revolução Verde. Acompanhando a disposição da agricultura moderna, assiste-se no Cerrado uma intensa reconfiguração socioespacial, que envolve o desmatamento e a substituição da vegetação nativa por monocultivos e um intenso processo de concentração urbana especialmente a partir da década de 1990, conforme evidencia MOYSÉS \& SILVA (2008).

É evidente, portanto, que a apropriação do Cerrado intensifica-se acompanhando os interesses e as estratégias do capital. Todavia, vale ressaltar que o modo de produção capitalista se hegemoniza no território, mas é preciso também considerar camponeses, povos cerradeiros, comunidades tradicionais, indígenas e etc que não possuem essa racionalidade econômica como centralidade. Mesmo que inseridos nesse sistema, esses sujeitos $(R e)$ Existem nesse processo, como bem evidencia MENDONÇA (2012). Entende-se que esses povos (Re)Existem, pois enfrentam a sua condição de existir, com o cerceamento de seus costumes, tradições, saberes fazeres e modo de vida pelo modelo hegemônico.

Percebe-se que com a modernização da agricultura, novo olhar voltou-se para o Cerrado. Esse território passou a ser considerado estratégico para os projetos expansionistas. Como afirmam CHAVEIRO \& CASTILHO (2010) "uma imagem positiva do Cerrado, edificada a partir da década de 1970, é paralela ao uso intenso dos componentes do bioma, coordenado por atores externos". A ocupação do Cerrado por esses "agentes externos" acontece paralela à reconstrução da imagem do bioma, impulsionada por interesses referentes a apropriação de seus componentes para produção agrícola. O Cerrado antes visto como "região das árvores tortas" passa a ser lido como "grande celeiro" ou "caixa d'água" e sua apropriação é motivada por programas governamentais agrícolas que permitem a ocupação produtiva como, por exemplo, o Programa de Desenvolvimento dos Cerrados (POLOCENTRO) e o Programa de Cooperação Nipo-Brasileiro para o Desenvolvimento dos Cerrados (PRODECER), como exemplifica SILVA \& ANJOS (2010). 
O POLOCENTRO tinha como principal objetivo desenvolver e modernizar as atividades agropecuárias, já o PRODECER, apresentava como intuito o desenvolvimento agrícola na região do Cerrado, aumentando a oferta internacional de alimentos, a exportação de produtos agrícolas e a incorporação do campo brasileiro no modo de produção capitalista como identifica PIRES (2000). Este autor assinala que esses foram programas implantados pelo governo federal e estavam aliados a outros incentivos públicos, que implicaram em mudanças sociais, econômicas e ambientais, reconfigurando o espaço regional.

Destaca também a criação do primeiro e do segundo Plano Nacional de Desenvolvimento (PND), na década de 1970 , os quais apresentavam como principais metas a modernização da agricultura, buscando dotá-las de bases empresariais. No entanto, "do conjunto dos programas agrícolas governamentais que influenciaram a ocupação do Cerrado, 0 de maior envergadura foi 0 PRODECER"; (PIRES, 2000), pois herdou o sucesso e o fracasso dos demais programas.

Importante é mencionar também o papel da criação da Empresa Brasileira de Pesquisas Agropecuárias (EMBRAPA), já que conforme explica PIRES (2000) esta foi criada em 1973, alavancando o desenvolvimento tecnológico que aproximou a indústria ao campo e que objetivava o aumento de produtividade no setor agrícola, gerando um excedente exportável. Entretanto, os benefícios desse desenvolvimento não chegaram a todos, ou ao menos, para a maioria. As políticas de créditos, como reafirma PIRES (2000) eram propositalmente direcionadas às grandes fazendas (essas eram consideradas mais adequadas à modernização). Nesse contexto, incentivavam o uso de pacotes tecnológicos e gerou-se concomitante a isso o aumento no preço da terra, restringindo-se o acesso a terra, as tecnologias e as políticas de crédito.

Nesse processo, como explica DELGADO (2012) uma das características do capitalismo, neste caso transfigurado no agronegócio - sobretudo a partir de 2000; foi tornar mercadoria o que seria de uso comum. Desse modo, solo, ar, água, vegetação, passam a ser denominados de "recursos naturais" consistindo como um verdadeiro recurso aos interesses do capital e sendo apropriado como tal. MENDONÇA (2004) ao pautar as disputas no Cerrado trata então da desterritorialização de camponeses e trabalhadores da terra (grifo do autor). $\mathrm{O}$ autor retrata como a pecuária extensiva e a agricultura tradicional deu lugar a agropecuária moderna, com a vinda dos donos do capital financeiro do sul de experiência acumulada desde o início da modernização da agricultura no país, que se instalaram na região apropriando-se dos recursos e modificando a realidade local.

A "desterritorialização de trabalhadores da terra" (MENDONÇA, 2004), portanto, acontece paralela à chegada dessas novas técnicas e tecnologias a favor de grupos restritos e associados a um modo de produção perverso. Esse processo de expropriação é também intensificado pelo uso de insumos químicos, a medida que:

os inseticidas [(por exemplo)] utilizados nas grandes plantações provocam as migrações das largatas e outros insetos, que acabam se refugiando nos cultivos menores, [do mesmo modo] a introdução da mecanização e das novas tecnologias por parte daqueles [favorecidos nesse modelo], problematiza e inquieta os pequenos agricultores, resultando, às vezes, no desprezo e desmotivação em relação as suas técnicas (IBASE,1986). 
Em trabalho de campo realizado pela autora em 2016 na microrregião de Pires do Rio, observou-se nitidamente realidade semelhante. Camponeses de práticas agroecológicas encontravam-se prejudicados pela mosca branca das lavouras de soja que hegemonizam aquele espaço. Análogo a isso, produtores de melancia da microrregião de Ceres, devido a aplicação desmedida e irregular de agrotóxicos em outros cultivos, foram prejudicados com a morte de abelhas que contribuem na polinização, segundo relatos de entrevistados.

Por isso, como já mencionado, é imprescindível dimensionar a capacidade de $(\mathrm{Re})$ Existência desses povos (MENDONÇA, 2012) e as estratégias do capital para o controle da terra. CHAVEIRO \& CASTILHO (2007) explicam que esse modelo de apropriação e uso das terras cerradeiras promove o homicídio do patrimônio cerradeiro. Entende-se que é um modelo, carregado de injustiças sociais e ambientais, sendo importante, nesse sentido, desvelar o conceito de "agronegócio" que enquanto conceito, não se restringe simplesmente a compreensão de negócio no campo como se sugere de forma imediata, mas trata-se de um projeto hegemônico (DELGADO, 2012), que envolve vários outros aspectos que vão para além da produção agrícola em si. Conforme sugere a análise do autor, o conceito Agronegócio é portanto polissêmico e não contempla a realidade empírica e as disputas assistidas no campo.

BEZERRA (2009) a esse respeito explana sobre a bagagem ideológica que acompanha o conceito de agronegócio. Para o autor "o agronegócio tem sido utilizado como a grande bandeira dos empresários agrícolas para colocar o setor como um dos mais promissores da economia brasileira". DELGADO (2012) faz uma leitura do período de transição da "Modernização Conservadora" a economia do Agronegócio. O período de transição entre esses dois projetos de economia política tem como marco temporal os anos 2000 , pós-crise cambial, que fornece a oportunidade ao agronegócio de apresentar-se como estratégia econômica. Assistese então o "relançamento da estratégia de reprimarização do comércio externo, a qualquer custo".

Após retomar para reflexão os processos que se configuram até a chegada concreta deste projeto, o autor acima apresenta uma análise pontuando os aspectos estruturantes, os efeitos e as bases que sustentam o agronegócio. "Em linhas gerais, trata-se este de um projeto de acumulação de capital no setor agrícola, concertado por dentro da política econômica e financeira do Estado" (2012,). Com o amparo do discurso midiático e a "ideia impacto" de produção de alimentos e especialmente commodities, voltadas a exportação, para o sustento da economia nacional, o agronegócio tem seu "sucesso" apoiado no investimento público no setor privado, no qual o Estado apresenta papel crucial, por meio de dívidas perdoadas e taxa de juros favoráveis ao projeto, como bem analisa o autor.

Não se pode desconsiderar entre tantos elementos e disputas que compõe o agronegócio, o papel da água nessa estratégia de territorialização do capital. No objetivo de contemplar esse importante fator estratégico, THOMAZ JÚNIOR (2010); alude o conceito de agrohidronegócio para subsidiar a leitura da apropriação em áreas de Cerrado. Entende que estudar o agrohidronegócio e os conflitos pelo uso da água no Cerrado, é portanto, compreender os atores que se territorializam, os efeitos econômicos, políticos e sociais, o uso e apropriação dos "recursos naturais" e etc. 


\section{Uso e ocupação da microrregião Ceres - GO}

A microrregião de Ceres está localizada na mesorregião do Centro Goiano e atualmente é composta por 22 municípios, conforme espacializado no mapa 1. Os municípios que compõem a microrregião, portanto, são: Barro Alto, Carmo do Rio Verde, Ceres, Goianésia, Guaraíta, Guarinos, Hidrolina, Ipiranga de Goiás, Itapaci, Itapuranga, Morro Agudo de Goiás, Nova América, Nova Glória, Pilar de Goiás, Rialma, Rianápolis, Rubiataba, Santa Isabel, Santa Rita do Novo Destino, São Luíz do Norte, São Patrício e Uruana. Sendo Ceres, o município que denomina a microrregião localizado a aproximadamente 170 km da capital Goiânia e Goianésia o município mais populoso desta (ARRAIS 2013).

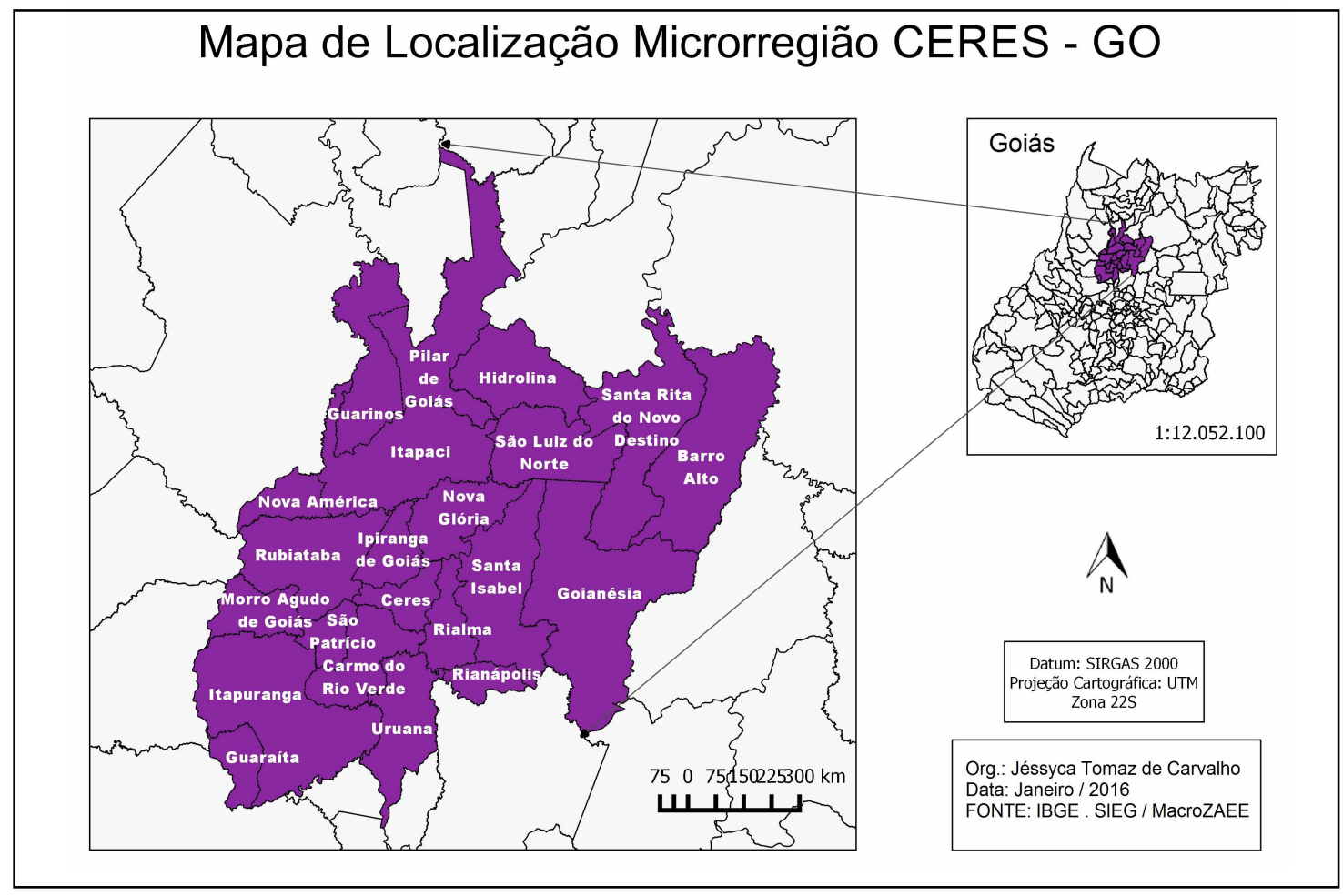

MAPA 1 - Mapa de Localização da Microrregião de Ceres-GO Fonte: IBGE; SIEG; MacroZAEE (2016). Elaboração: Autora (2016).

O processo de ocupação e apropriação do espaço que hoje configura a microrregião possui alguns marcos que envolve a incorporação do território goiano ao sistema de produção capitalista. ARRAIS (2013) destaca o regime de acumulação do Sudeste brasileiro e o quadro de desigualdade regional, herdado do período colonial, como alguns desses marcos.

Como já mencionado, ao periodizar o processo de ocupação do Cerrado, a Marcha para o Oeste, projeto implementado no governo Vargas na década de 1930, tem grande destaque. Conforme afirma CASTILHO (2012) "os projetos de Vargas muito influenciaram a configuração territorial da região central de Goiás denominada, naquele período, de Mato Grosso Goiano" com destaque a criação da Colônia Agrícola Nacional (CANG), criada no atual município Ceres.

A CANG teve influência direta na configuração territorial e dinâmica populacional desse espaço conforme esclarece o autor. Nesse processo, é válido ENCICLOPÉDIA BIOSFERA, Centro Científico Conhecer - Goiânia, v.14 n.25; p.1719 2017 
destacar a posterior construção de estradas (como a rodovia federal) e outras infraestruturas que possibilitavam o escoamento de matéria-prima e a aproximação da microrregião com outras regiões do país, o que pode ser compreendido pelo histórico-cidades do IBGE. A economia local nesse período, pautava-se sobretudo na pecuária extensiva e na produção de grãos, bem como elucida FERREIRA (2010);

\begin{abstract}
a CANG de Goiás apresentou muitos de seus objetivos frustrados, mas teve função significativa no que se refere à ocupação, fixação do homem à terra e promoção da expansão da fronteira agrícola, por meio de uma agricultura moderna, além de ser considerada o principal projeto da "Marcha para o Oeste" no que se refere à ocupação da microrregião.
\end{abstract}

Nota-se portanto, que o primeiro, marco na dinâmica populacional da microrregião, se deu com a criação da CANG e a migração de famílias (sobretudo mineiras) para este espaço. A construção de Brasília e de rodovias no governo de Juscelino Kubitschek, também foram importantes fatores que influenciaram na ocupação do Cerrado Goiano, já que promoveu o acesso de outras regiões a região Centro-Oeste (FERREIRA (2010). Como evidencia ARRAIS (2013) o processo de modernização da agricultura não se restringiu a mudança da base técnica e ao aumento da produtividade, de modo que envolve uma relação espaço-tempo que perpassa a redução de cultivos tradicionais, a produção de commodities, a transformação das condições de trabalho no campo, a perda da biodiversidade entre outros fatores. Observa-se, todavia, a expansão canavieira como uma das faces do agronegócio e a produção de commodities.

\title{
Os efeitos da territorialização do agronegócio sucroenergético para a microrregião de Ceres-GO
}

Além dos programas já mencionados, que influenciaram no processo de uso e ocupação do Cerrado Goiano, FERREIRA (2010) destaca o Programa Nacional do Álcool (Proálcool), criado no Brasil no ano de 1975, como outro programa que contribuiu para a incorporação de Goiás a esse modelo de produção agrícola, especialmente a microrregião de Ceres. A autora elucida que:

a origem do Proálcool esteve vinculada à intenção de tornar o mercado favorável para os produtores de cana-de-açúcar, por meio de incentivos à produção de álcool carburante (buscando substituir, naquele momento a produção de açúcar por álcool), bem como resolver o problema de abastecimento interno de combustível, o qual começava a ser sentido, devido à crise mundial do petróleo em 1973 (FERREIRA, 2010).

Os incentivos do Proálcool e demais estímulos e fomentos do Estado, proporcionaram a instalação de usinas e a expansão canavieira na microrregião. FERREIRA (2010) exemplifica tal realidade citando as usinas Pite S/A (em Itapuranga), Devale (Itapaci), Usina Goianésia e Jalles Machado (ambas em Goianésia) e Carval (em Carmo do Rio Verde), instaladas, a primeira, no final da década de 1970 e as demais no decorrer da década de 1980. 
A instalação de agroindústrias e o processo de territorialização do agronegócio nesse espaço apresentou-se como novo marco na dinâmica populacional da microrregião. FERREIRA (2010) destaca que no ano 2000, foi criado o Programa de Desenvolvimento Industrial de Goiás - PRODUZIR - que primeiramente teve a intenção de substituir o FOMENTAR já que a princípio o prazo para este expirar era de apenas 10 anos. Esse programa, também teve desempenho no fomento e incentivo para a instalação de agroindústrias; a autora explica que:

\begin{abstract}
em linhas gerais, o Produzir trata-se de um incentivo financeiro de apoio às indústrias, com base no faturamento e arrecadação tributária. O Produzir visa amparar principalmente projetos industriais direcionados à implantação de novos empreendimentos; expansão e diversificação da capacidade produtiva; modernização tecnológica; gestão ambiental; revitalização de unidade industrial paralisada. Em síntese, características que estimulam a competitividade e a capitalização no campo. (FERREIRA, 2010).
\end{abstract}

ARRAIS (2013) explica que o Estado produz território, por meio, por exemplo, da dotação de infraestrutura, a regulamentação jurídica, o financiamento da produção e etc; por isso, entende-se, a expansão canavieira, como um processo de territorialização do agronegócio sucroenergético. Os mapas 2 e 3 apresentam esta territorialização, por meio da expansão da área colhida de cana-de-açúcar em HA nos anos 2000 e 2002.

\title{
PRODUÇÃO DE CANA-DE-AÇÚCAR NA MRG CERES (2000)
}
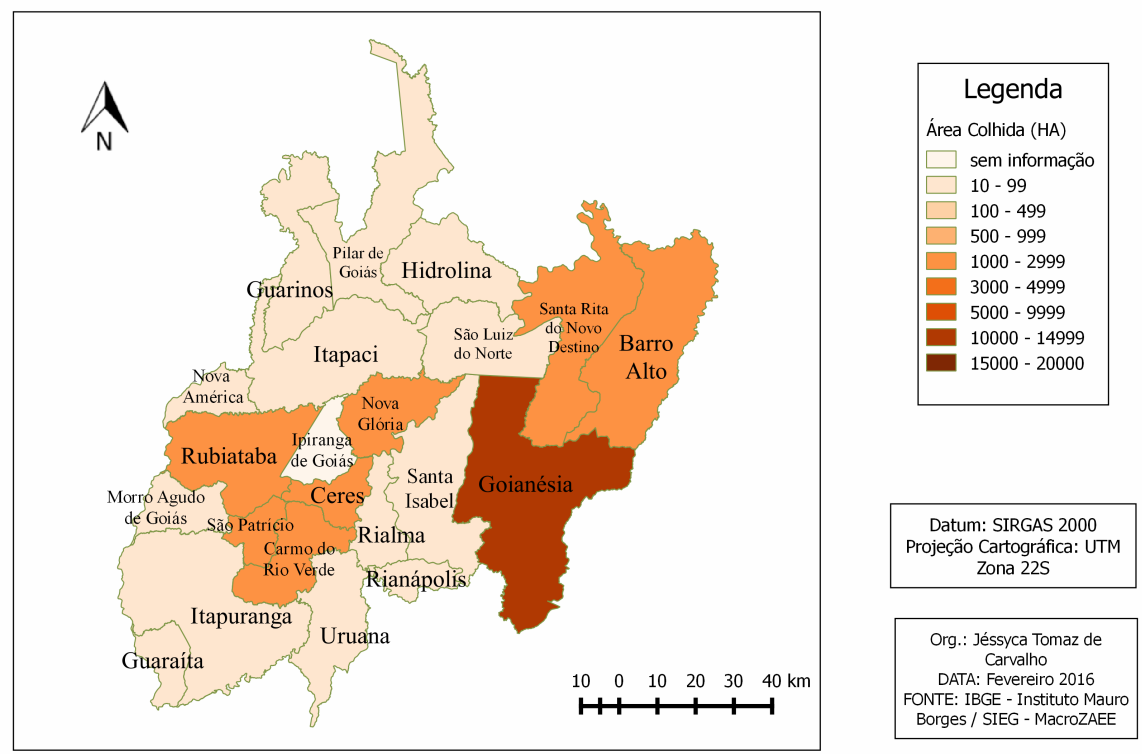

MAPA 2- Produção de cana-de-açúcar na MRG de Ceres em 2000 - área colhida (HA) Fonte: IBGE; SIEG; MacroZAEE (2016). Elaboração: Autora (2016). 


\section{PRODUÇÃO DE CANA-DE-AÇÚCAR NA MRG CERES (2002)}
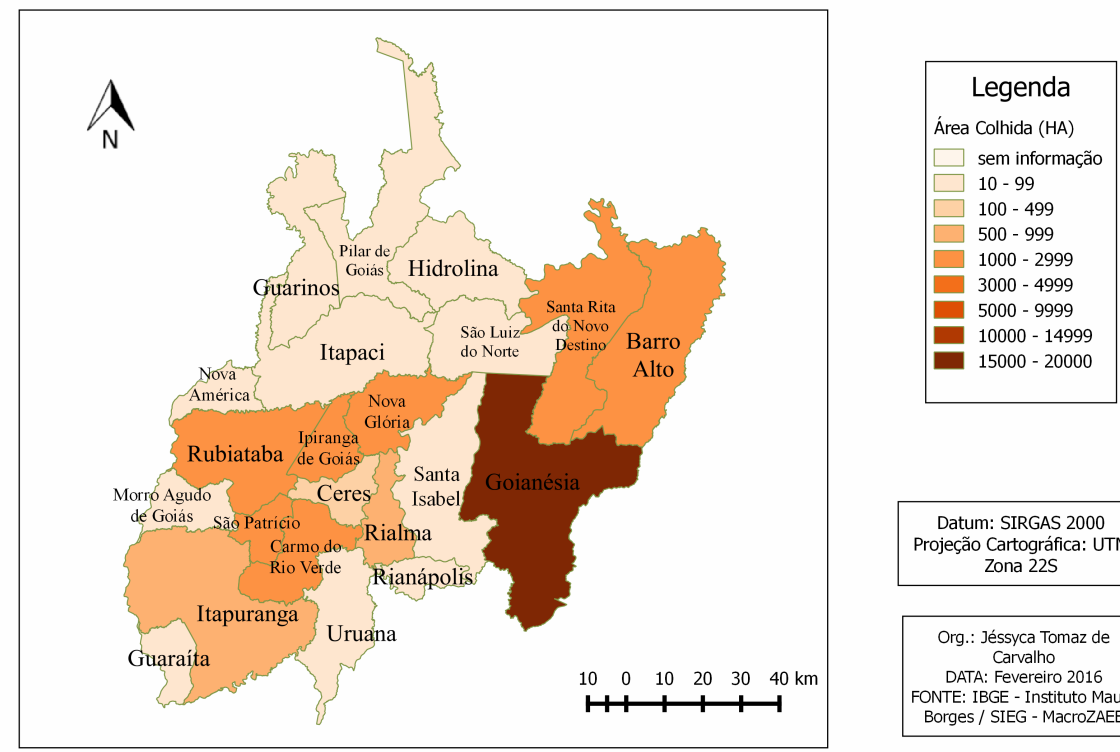

Datum: SIRGAS 2000 Projeção Cartográfica:

Org.: Jéssyca Tomaz de
Carvalho
DATA: Fevereiro 2016
FONTE: IBGE - Instituto Mauro
Borges / SIEG - MacroZAEE

MAPA 3 - Produção de cana-de-açúcar na MRG de Ceres em 2002 - área colhida (HA) Fonte: IBGE; SIEG; MacroZAEE (2016). Elaboração: Autora (2016).

Observa-se que o município de Goianésia, desde o ano 2000 já apresentava extensas áreas com produção de cana-de-acúcar, entre 10000 e 20000 hectares, realidade justificada pela estabilização de algumas usinas no município como a Jalles Machado. Por conseguinte, municípios como Barro Alto e Santa Rita do Novo Descoberto, também são envolvidos nessa lógica produtiva, pela proximidade com a usina, haja vista que as lavouras de cana-de-açúcar devem estar há no máximo $50 \mathrm{~km}$ da usina, aproximadamente, para que haja lucro efetivo, conforme afirma SILVA (2016) (informação verbal) ${ }^{1}$.

FERREIRA \& DEUS (2010) identificam que em 2002, entrou em funcionamento em Carmo do Rio Verde a usina CRV Industrial do grupo Japungu da Paraíba, que em 2001 comprou a desativada Carval. Tal fato implicou na expansão da produção de cana-de-açúcar nos municípios limítrofes a Carmo do Rio Verde, incorporando novas terras. E em 2002 também, entrou em funcionamento a usina Vale Verde em Itapaci, unidade do grupo Farias. Por meio da análise do mapa 4, comparando-o com os mapas 2 e 3 é possível perceber a consolidação desse processo de instalação de novas usinas na microrregião.

\footnotetext{
${ }^{1}$ SILVA, Willian F. . Tese de doutorado - A agroindústria canavieira em Goiás: a questão técnicogerencial e as estratégias de controle fundiário - defendida em 04 de março de 2016 na sala A-19 do Instituto de Estudos Socioambientais da Universidade Federal de Goiás. Goiânia, 2016.
} 

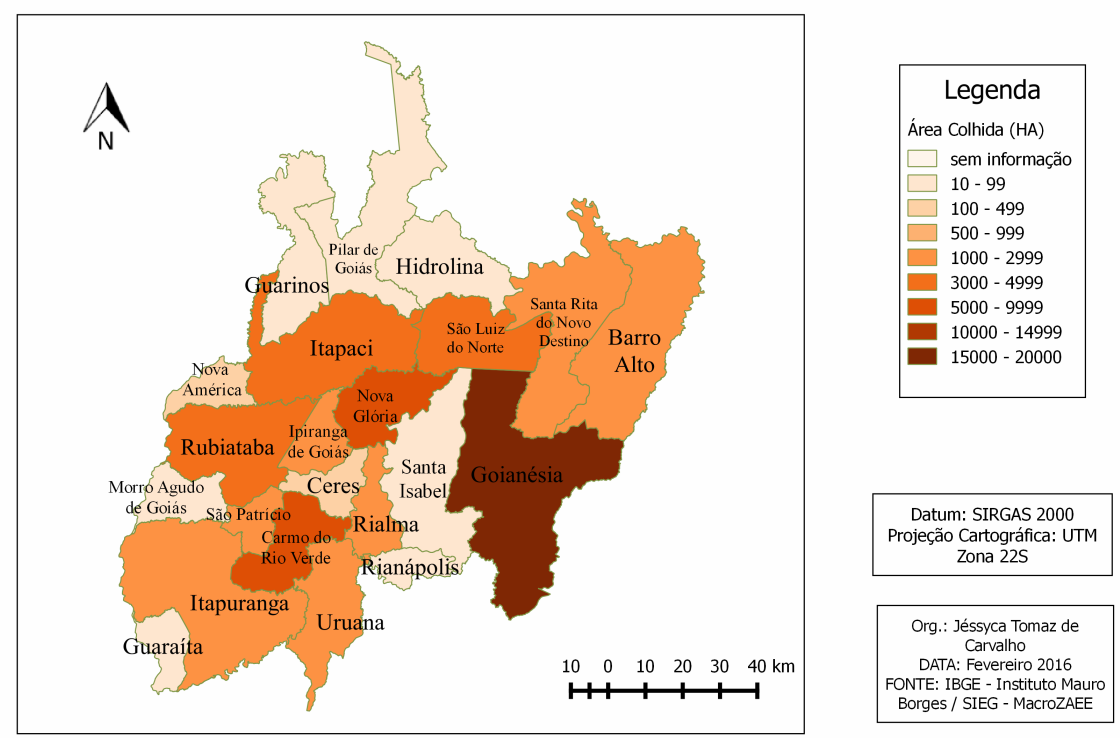

MAPA 4 - Produção de cana-de-açúcar na MRG de Ceres em 2004 -área colhida (HA)

Fonte: IBGE; SIEG; MacroZAEE (2016). Elaboração: Autora (2016).

A produção de carros flex a partir de 2002 foi outro marco na expansão da produção canavieira, este fator deve ser considerado na análise. Em 2006 foi lançado no Brasil o Plano Nacional de Agroenergia, (PNA 2006 - 2011), que também influenciou diretamente na produção de cana-de-açúcar na microregião de Ceres-GO (MAPA, 2006). O plano delineia como principal objetivo:

\begin{abstract}
estabelecer marco e rumo para as ações públicas e privadas de geração de conhecimento e de tecnologias que contribuam para a produção sustentável da agricultura de energia e para o uso racional dessa energia renovável. Tem por meta tornar competitivo o agronegócio brasileiro e dar suporte a determinadas políticas públicas, como a inclusão social, a regionalização do desenvolvimento e a sustentabilidade ambiental (BRASIL, 2006, p. 08).
\end{abstract}

Em maio de 2006, o Ministério da Agricultura Pecuária e Abastecimento (MAPA) veiculava a seguinte notícia "Brasil deve produzir safra recorde de cana-deaçúcar na safra 2006/2007", acrescentando ainda que "de acordo com a Conab, o crescimento se deve à ampliação e à abertura de novas usinas e destilarias para atender a fabricação de açúcar e álcool." Em abril de 2009, o MAPA anunciava:

Brasil bate mais um recorde na produção de cana-de-açúcar. [...] Entre os fatores que contribuíram para o crescimento estão 28 milhões de toneladas de cana madura remanescentes da safra de 2008, que serão moídas neste período, e a ampliação de $9,9 \%$ da área plantada, consequência da entrada em operação de aproximadamente 25 novas usinas. Até o ano passado, os canaviais destinados à indústria sucroalcooleira ocupavam 7,08 milhões de hectares e agora chegam a 7,79 milhões de hectares. [...] Os 
destaques são a expansão do plantio em Goiás, com 527,6 mil hectares (+31,3\%), e em Mato Grosso do Sul, com 335,1 mil hectares $(+21,5 \%)$. Na soma, o Centro-Oeste registra crescimento de $20,50 \%$, alcançando 1,09 milhão de hectares. A produção segue a mesma tendência, cerca de $30 \%$ maior $(85,29$ a 87,01 milhões de toneladas) (BRASIL, 2009).

A notícia elucidou a dimensão da territorialização canavieira na região CentroOeste, os mapas 5 e 6 evidenciam a expansão na área cultivada nos anos de 2006 e 2008 na microrregião de Ceres. Ficou evidente também o papel do incentivo do PNA nesse processo de territorialização, à medida que, conforme se observa nos dois mapas que seguem, há uma considerável elevação das áreas colhidas (BRASIL, 2009).

Observa-se no mapa que Goianésia apresentou uma relativa diminuição na área colhida, de 2006 para 2008, mantendo-se ainda assim, extensas áreas - acima de 10000(HA). Em contrapartida, em municípios limítrofes aos municípios com unidades de processamento, como Santa Isabel e Itapuranga, observa-se um aumento da área colhida.

\section{PRODUÇÃO DE CANA-DE-AÇÚCAR NA MRG CERES (2006)}
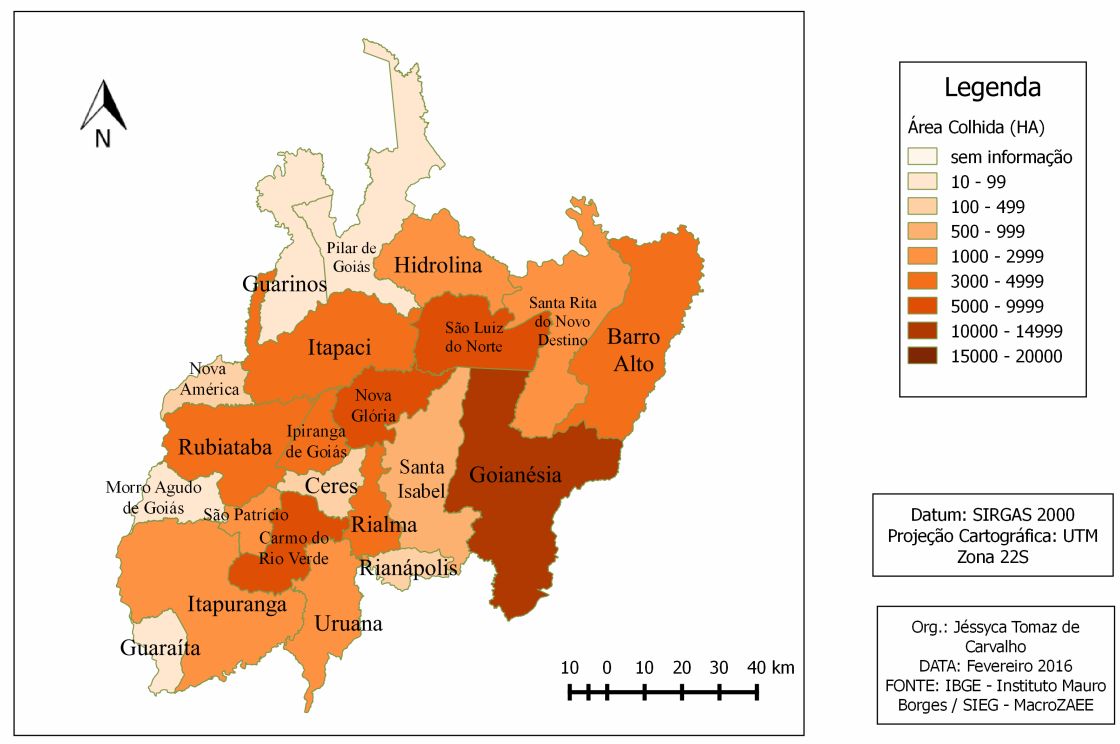

MAPA 5 - Produção de cana-de-açúcar na MRG de Ceres em 2006 -área colhida (HA) Fonte: IBGE; SIEG; MacroZAEE (2016). Elaboração: Autora (2016). 


\section{PRODUÇÃO DE CANA-DE-AÇÚCAR NA MRG CERES (2008)}
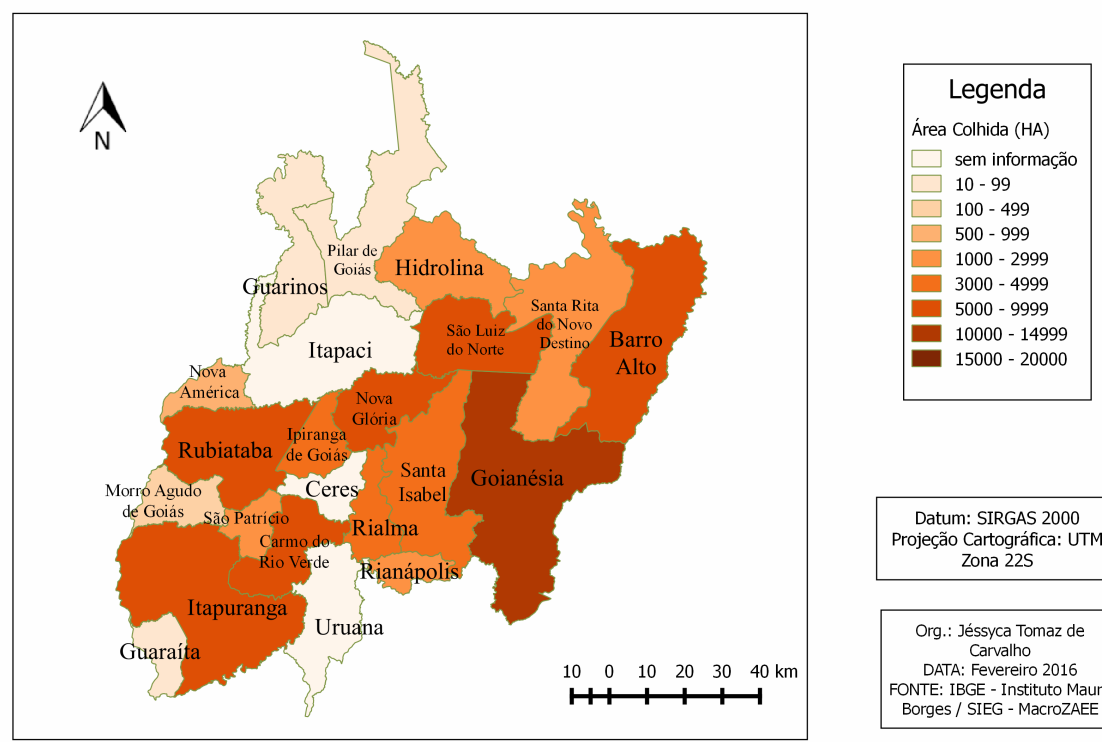

Datum: SIRGAS 2000 Zona $22 \mathrm{~S}$

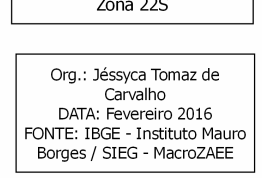

MAPA 6 - Produção de cana-de-açúcar na MRG de Ceres em 2008 - área colhida (HA) Fonte: IBGE; SIEG; MacroZAEE (2016). Elaboração: Autora (2016).

Torna-se pertinente considerar na análise, a global crise financeira de 2008. Em 2011, o MAPA veiculou a notícia de que o recorde de produção foi novamente superado. CASTRO (2013) sobre a expansão canavieira no estado de Goiás apontou que a partir da criação do Plano Nacional de Agroenergia, notou-se a intensificação da expansão da produção de cana-de-açúcar no território goiano (informação verbal) ${ }^{2}$. A homilia sobre a territorialização da produção canavieira perpassava o propósito de "substituição de áreas de pastagem degradas", entretanto, em Goiás, a proposta se contém apenas ao plano do discurso.

A professora assinala ainda que a maioria das usinas e cultivos no estado estão localizadas em área de agricultura. A logística e o preço da terra são os principais motivadores que fazem com que haja a ocupação inclusive de locais com solo arenoso. O comprometimento da biodiversidade com a expansão canavieira é apenas um dos efeitos dessa ocupação sem consciência, justiça social, ou proteção do ambiente; fator ainda agravado pelo permissivo novo código florestal (CASTRO 2013).

Outro fato importante pontuado por CASTRO (2013) e outros autores, é o de que a cana-de-açúcar em relação as demais culturas exige mais água (informação verbal) ${ }^{3}$. THOMAZ JÚNIOR (2010) a esse respeito elenca os conflitos e disputas territoriais que o leva a entender a imposição do agrohidronegócio. $\mathrm{O}$ autor explica que:

os aspectos essenciais desse processo de expansão dos agronegócios se consolida territorialmente, de forma enfática, em várias porções do espaço, mas [enfatiza-se] o que se passa

\footnotetext{
2 Palestra proferida por CASTRO, Selma Simões. Painel II: Expansão da cana-de-açúcar e os efeitos socioambientais nas áreas de Cerrado. In.: 10 WORKSHOP SOBRE "A EXPANSÃO DA AGROINDÚSTRIA CANAVIEIRA EM GOIÁS -BRASIL: EFEITOS SOCIOAMBIENTAIS E PRECARIZAÇÃO DO TRABALHO NO CAMPO". Goiânia: Universidade Federal de Goiás, Instituto de Estudos Socioambientais: 09 dez 2013.
} 
especificamente à sua complexa expressão/composição canavieira. [...] As ações que antepõem trabalhadores x capital, as fissuras intercapital reveladas pela necessidade de terras planas, férteis e com disponibilidade hídrica - portanto aptas à mecanização -, e entre os próprios trabalhadores, são, por excelência, os exemplos das disputas por território que revelam o conteúdo e os significados do processo expansionista do agronegócio em geral (THOMAZ JÚNIOR, 2010, 94-95).

Desse modo, "o sucesso do agronegócio não pode ser atribuído somente a sua fixação a territorialização e/ou monopolização das terras, mas também ao acesso e controle da água, assim como as demais etapas da cadeia produtiva, comercialização etc" (THOMAZ JÚNIOR, 2010). Essa apropriação dos recursos hídricos assistida com a "destrutiva expansão do capital" é entendida também por FREITAS \& CLEPS JÚNIOR (2012) que advertem que:

ao acompanhar os investimentos oriundos do agrohidronegócio sucroenergético, verifica-se o fortalecimento das áreas tradicionais, assim como a delimitação de novas áreas. Para garantir sua territorialização, o agronegócio utiliza diversos instrumentos e estratégias, seja na busca pela titulação da terra (legal ou grilada), contratos de arrendamentos ou mesmo a compra de terras e a instalação de unidades de processamentos. (FREITAS \& CLEPS JÚNIOR, 2012, p. 180).

São nítidos os problemas arrastados desde o período colonial quanto a questão agrária no Brasil. Como já mencionado, o processo de concentração latifundiária, tem se intensificado especialmente com a inserção do capital no espaço agrário e o aporte do Estado. $\mathrm{Na}$ análise sobre a territorialização do agronegócio sucroenergético, percebe-se o arrendamento de terras como um novo fator de dependência e subordinação ao capital. Os mapas 7 e 8 evidenciam como 0 processo de territorialização do setor sucroenergético, e por conseguinte, o controle da terra foi se intensificando (FREITAS \& CLEPS JÚNIOR, 2012).

PRODUÇÃO DE CANA-DE-AÇÚCAR NA MRG CERES (2010)
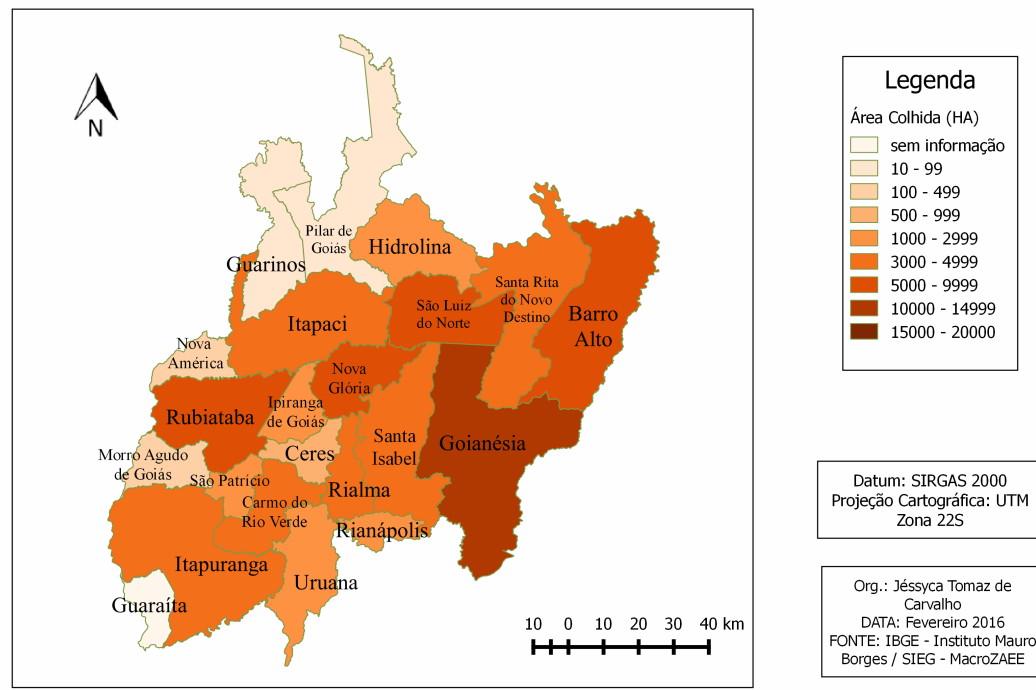

rojeção Cartográfica: UTM Zona 22S

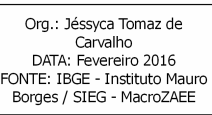

MAPA 7 - Produção de cana-de-açúcar na MRG Ceres em 2010 - área colhida (HA) Fonte: IBGE; SIEG; MacroZAEE (2016). Elaboração: Autora (2016). 
PRODUÇÃO DE CANA-DE-AÇÚCAR NA MRG CERES (2012)
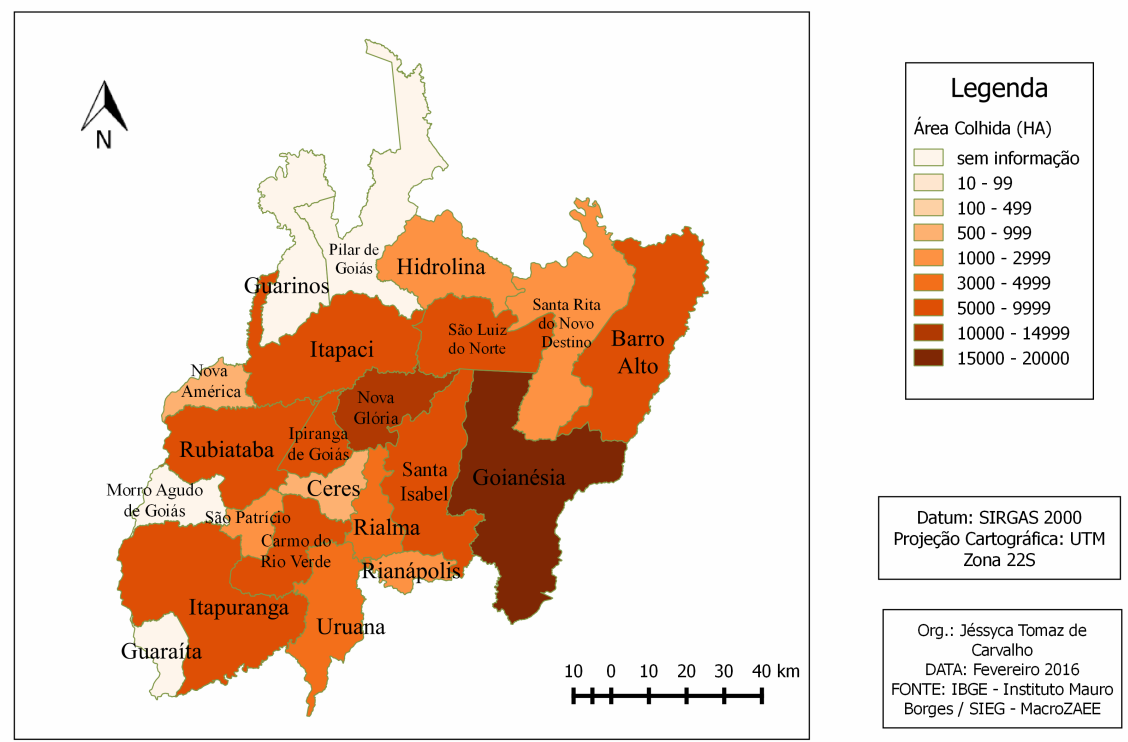

MAPA 8 - Produção de cana-de-açúcar na MRG de Ceres em 2012 - área colhida (HA) Fonte: IBGE; SIEG; MacroZAEE (2016). Elaboração: Autora (2016).

Observa-se a partir dos dados disponibilizados pelo IBGE e especializados pela autora no mapa, que apenas o município de Santa Rita do Novo Destino, teve uma redução na área colhida de cana-de-açúcar, entre os demais municípios oito estabilizaram-se, relativamente, oito apresentaram considerável aumento na área colhida. Exemplo disso são os municípios de Uruana, que atingiu em 2012 a classe de 1000 a 3000 (HA) de área colhida, Nova Glória, que no mesmo ano chegou a classe entre 10000 e 15000 (HA) e Goianésia que ultrapassou os 15000 (HA). Evidenciando novamente o processo de territorialização do setor sucroenergético na microrregião.

Relatos obtidos em pesquisa de campo realizada pela autora no segundo semestre de 2015 complementam a interpretação desse processo. Observa-se que diferentes leituras são feitas pelos sujeitos que convivem e são diretamente influenciados pela expansão canavieira. Um produtor de melancia do município de Uruana, por exemplo, afirma que "o arrendamento é um negócio lucrativo, mas para quem é proprietário de terra grande, ou de muitas terras".

Já para outro produtor de melancia entrevistado da microrregião, "um dos principais problemas do arrendamento para a produção canavieira, está nos ciclos que tornam o proprietário da terra dependente da usina. Ao arrendar sua terra por cinco anos ou mais ou renovar o ciclo, a cada ano o proprietário perde um pouco mais da qualidade de sua terra, desse modo, se algum dia precisar ou quiser retomar outros cultivos em sua propriedade, caso a usina não queira ou não precise mais alugar aquela terra, terá dificuldades".

O relato do primeiro produtor revela sobre a preocupação quanto ao arrendamento da terra. O produtor não reconhece prejuízos sociais para o município, nem vê a produção de cana como uma ameaça ao solo; mas é consciente quanto ao risco de arrendar a terra pelo longo comprometimento com a 
usina e incerteza sobre o amanhã, considerando um negócio lucrativo apenas para aqueles que têm outras garantias de renda.

Para outros trabalhadores entrevistados pela autora a produção de canade-açúcar pode render lucro ao dono da terra por algum período, entretanto reconfigura a dinâmica da cidade e pode atrair sérios problemas ao município do ponto de vista social e ambiental, além de promover a degradação da propriedade. Um jovem, filho de camponês entrevistado, afirmou que em sua opinião "o arrendamento para a produção de cana, pode até ser um negócio lucrativo", relatando a experiência de seu pai e tios: "já conseguiram até 90 mil reais por ano", mas concluiu que "em nenhum outro tipo de produção, ele presenciou tanto desmatamento, perda de fertilidade do solo, uso tão intensivo da água e depredação da propriedade em termos de infraestrutura".

Nota-se pela fala do jovem os desafios de retorno ou fixação do camponês no campo, durante ou após o arrendamento da terra para a produção de cana-deaçúcar. Vários camponeses associam também o surgimento de viroses e outros problemas com pragas e etc. à expansão canavieira, afirmando que além de terem suas lavouras (outros cultivos) prejudicadas, aumenta-se, por conseguinte o custo da produção, havendo também grande interferência na qualidade do produto, em função da dependência gerada quanto ao uso de agroquímicos. GRAZIANO NETO (1982) ao tratar das consequências da modernização da agricultura para os ecossistemas naturais, já percebia que:

o aparecimento de pragas e doenças nas culturas relaciona-se com as condições do solo e seu manejo. [...] Práticas inadequadas podem levar a que as plantas tenham seu crescimento comprometido, e, sob certas condições, a adição de adubos químicos sintéticos provoca desequilíbrio no metabolismo vegetal, devido à absorção desbalanceada de nutrientes. [...] A praga ou seu aparecimento é, nesse sentido, um importante indicador biológico de que algo foi ou está sendo drasticamente alterado no ecossistema (GRAZIANO NETO, 1982, p. $101-102)$.

Nesse sentido, pela perspectiva do autor acima , o que deveria importar ao agrônomo ou produtor seriam as condições e causas do surgimento de pragas e não as pragas em si. Para ele a Revolução Verde e os pacotes tecnológicos geraram certa comodidade por um viés de solução imediata dos problemas, sem pensar em suas consequências. Acrescenta, assim como observado pelos camponeses, que "os agrotóxicos são como drogas: [...] o aumento no desequilíbrio do ecossistema cria uma dependência pelo produto químico". O cerceamento da racionalidade camponesa do ponto de vista social, ambiental, produtivo e etc. apresenta-se, portanto, como preocupante efeito da territorialização do agronegócio sucroenergético.

Em mesma pesquisa de campo realizada pela autora em 2015, secretários do Meio Ambiente que trabalham em municípios da microrregião, afirmaram que a maior preocupação ambiental da Secretaria é quanto ao desmatamento, a disputa pelos recursos hídricos e o comprometimento do solo e da água pelo cultivo, agravado pelo uso de insumos. Os mesmos consideram a contribuição do setor sucroenergético para a economia local algo mínimo frente à esses "impactos ambientais" [sic]. 
DEUS (2015) a esse respeito, afirma que o setor sucroenergético, em maioria formado por grandes grupos, gera uma dependência de uma única estrutura econômica que não gera lucro para a economia local. Destaca também que é um setor sustentado pelo Estado ou pela população (informação verbal) ${ }^{4}$. Os secretários salientam que "as terras majoritariamente, arrendadas, são intensamente degradadas, quanto a qualidade do solo e a infraestrutura e frequentemente nota-se a tentativa de rescisão de contratos, tentativas essas frustradas a medida que o produtor, torna-se cada vez mais dependente do setor". O mapa 9 apresenta dados do último censo, quanto a área colhida na microrregião em 2014.

\section{PRODUÇÃO DE CANA-DE-AÇÚCAR NA MRG CERES (2014)}
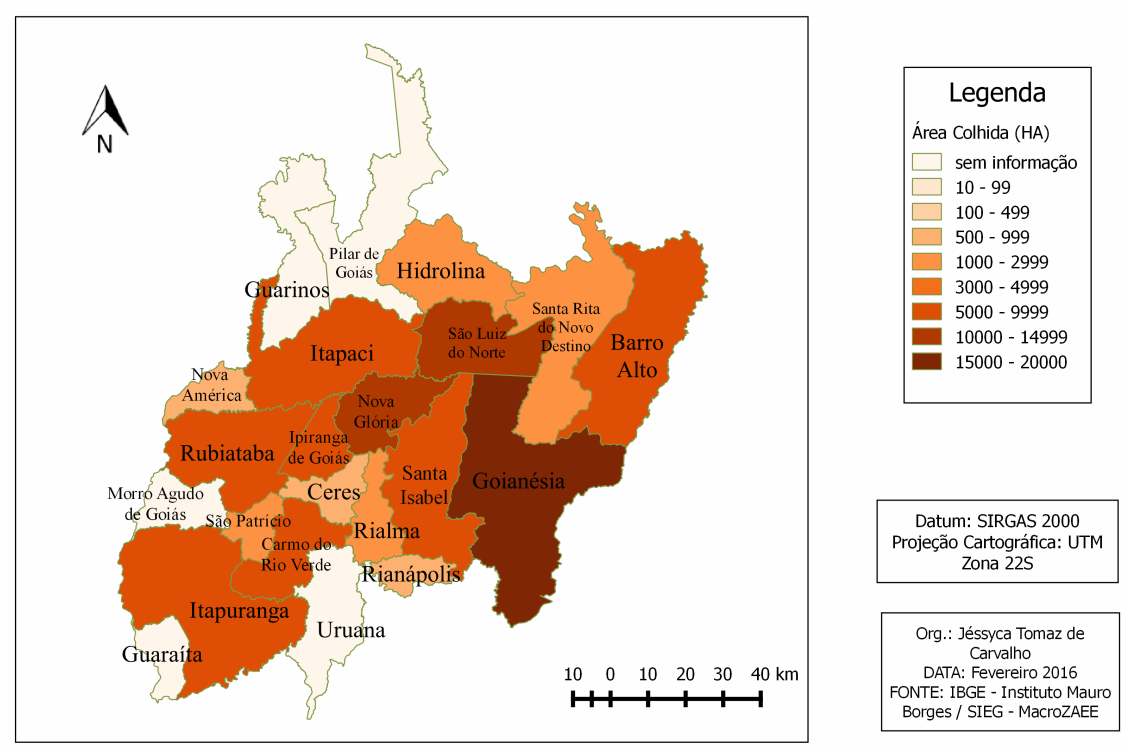

MAPA 9 - Produção de cana-de-açúcar na MRG Ceres em 2012 - área colhida (HA)

Fonte: IBGE; SIEG; MacroZAEE (2016). Elaboração: A autora (2016).

Nota-se pelo mapa que de 2012 a 2014 praticamente todos os municípios mantiveram-se na mesma classe quanto a área colhida, com exceção de Rianápolis que mantendo pequena área colhida, reduziu ainda para menos de 500 (HA). Entretanto, destaca-se o município de São Luiz do Norte, que atingiu a classe entre 10000 e 15000 (HA), assim como Nova Glória, que se manteve nessa classificação.

Para o secretário de meio ambiente, de um dos municípios ${ }^{5}$, entrevistado pela autora em 2015 entre os prejuízos ambientais e sociais dessa expansão observam-se os problemas quanto a queima e o corte da cana, que é algo frequente na microrregião ainda que haja a substituição gradativa do corte manual pela mecanização. Entre os problemas desse tipo de manejo destacam-se a degradação do trabalhador, a perda de espécies da fauna local, acidentes frequentes em estradas e rodovias por razão da fumaça e problemas respiratórios para a população pelo mesmo motivo.

\footnotetext{
${ }^{4}$ DEUS, João Batista de. Fala proferida na aula da disciplina "Ambiente e apropriação da Região do Cerrado" do Programa de Pós-Graduação em Geografia da UFG, no dia 24 de novembro de 2015, no auditório do Instituto de Estudos Socioambientais da Universidade Federal de Goiás. Goiânia, 2015. ${ }^{5} \mathrm{O}$ mesmo solicitou que não fosse identificado.
} 
O secretário considera a ausência de fiscalização a principal dificuldade e apresenta que essa é uma realidade de considerável parte da região. Explica que como proposta de intervenção, as secretarias têm como projeto a recuperação de áreas de nascentes degradadas, com o plantio de mudas e destacam o papel da comunidade e da participação desta na fiscalização. Para o secretário entrevistado é importante destacar também os trabalhos de extensão que viabilizam a sensibilização da população quanto aos problemas ambientais. Nesse sentido, a Universidade para ele apresenta-se como relevante via de contribuição. Já que o diálogo coerente entre as secretarias, a Agência Rural (com seu poder de articulação e influência), a Universidade e a população local pode ser bastante propositivo no que tange a educação ambiental, bem como, na fiscalização - uma das demandas locais.

Em relação aos trabalhadores da lavoura de cana-de-açúcar, o secretário entrevistado afirma que são pessoas oriundas especialmente da região Nordeste do país e que migram sozinhos e com suas famílias. Em entrevista com representante do sindicato do trabalhador rural, identificou-se que em geral, os homens trabalham no corte da cana e as mulheres, dedicam-se ao serviço doméstico. Para o secretário e para a representante do sindicato, atualmente, não mais há um estranhamento da população local quanto a essa população migrante.

Outro efeito a ser analisado, é a respeito das condições de trabalho assistidas nos canaviais, sobretudo no corte da cana. Em entrevista realizada pela pesquisadora em 2015 e 2016, com 07 trabalhadores do corte da cana de uma das usinas da microrregião, foi possível observar que este ainda é um dos aspectos da produção carregados de perversidade, exploração e condições de trabalho análogas ao escravo em um cenário nacional. Um dos trabalhadores, veio da Paraíba e trabalha há 15 anos no corte de cana; trabalhou em diferentes usinas em Goiás, Mato Grosso e São Paulo. Ressalva que a partir do sexto ou oitavo ano de trabalho já não apresentava a mesma condição física. Para ele "um dos problemas é a relação com os fiscais e a precariedade nas condições no momento de se alimentar".

O trabalhador afirma que "muitos trabalhadores são prejudicados por não conhecerem seus direitos e acredita que poderiam obter maiores conquistas se conseguissem se articular melhor". Entretanto, o mesmo esclarece que "a rotatividade dos trabalhadores, é inclusive, uma das estratégias das usinas para impossibilitar essa ação". Para outro trabalhado entrevistado, "a exaustão e exploração do trabalhador está diretamente ligada ao modelo produtivo, já que o ganho é proporcional a produtividade". Ambos ressalvam a importância da sensibilização dos trabalhadores sobre seus direitos, para que tal fato não seja ainda mais agravado e a necessidade de uma "aproximação recíproca entre trabalhadores e sindicatos". Para um terceiro trabalhador entrevistado "a relação entre trabalhadores e sindicatos constitui-se enquanto um entrave".

Em pesquisa de campo, realizada em 2015, em entrevista com um morador local, motorista de colheitadeira de arroz e milho, obteve-se o relato de que o único benefício que o mesmo percebia do setor canavieiro para o município, era a contribuição destes trabalhadores para o comércio e serviços locais. Sobre a concentração e controle das terras pelo setor, o mesmo se atenta ao fato de que "as maiores terras são arrendadas para a produção de cana-de-açúcar e que as propriedades fragmentadas por herança em geral são rapidamente vendidas ou 
arrendadas, a medida que os filhos não conseguem obter renda da terra e viver no campo".

O trabalhador supracitado considera que "a expansão canavieira ilha os camponeses e interfere diretamente na produção de alimentos, deixando-os suscetíveis a possibilidade de venda ou arrendamento das terras". Para ele "a criação de feiras no município, tem contribuído para incentivar que essa população fique no campo e produza alimentos. Tais feiras são organizadas por associações e tem tido relevante aceitação da população urbana".

No que tange os efeitos da territorialização do setor sucroenérgetico para o Cerrado, sobretudo enquanto bioma, observa-se que desde a década de $1960 \mathrm{com}$ os primeiros projetos de modernização da agricultura, já era possível observar a apropriação e comprometimento dos seus componentes naturais, como para KLINK \& MACHADO (2005) "A degradação do solo e dos ecossistemas nativos e a dispersão de espécies exóticas são as maiores e mais amplas ameaças a biodiversidade". Em trabalho de campo realizado pela autora em 2015 em Quirinópolis, que apresenta realidade muito similar, foi possível averiguar tal realidade com a fala de um camponês que migrou da microrregião de Ceres para este município.

O camponês relata sobre sua experiência no chamado "Vale do São Patrício" na década de 1960/1970, afirmando que "com a chegada da usina na região, terras eram arrendadas e não se recebia pela área de preservação, pelos córregos e outros componentes do Cerrado, que eram utilizados pelo setor". O camponês complementa "mesmo que degradassem o meio ambiente, não pagavam por esse recurso e devolviam as terras em péssimas condições". Para o camponês "este é um dos setores mais perversos do agronegócio, com problemas internos e externos a produção". Relata que "a expansão canavieira provoca a expulsão das pessoas do campo, além disso, não oferece oportunidades para essas pessoas, 0 que gera consequências inclusive para o espaço urbano".

\section{CONSIDERAÇÕES FINAIS}

Nota-se que a questão da Soberania Alimentar, é ponto de pauta e importante agenda de pesquisa ao se problematizar os efeitos da territorialização canavieira no Cerrado, dentro desse molde de produção baseado na concentração de terras, de produção, de lucros e etc. A partir da instituição de um modelo de exploração, baseado na lógica econômica global capitalista, a maioria das áreas de Cerrado foram degradadas.

Considera-se aqui que o problema não está na ocupação humana ou na modernização da agricultura. O problema é quando esses processos se balizam somente no critério econômico, não havendo o equilíbrio com outros critérios como sociais, ambientais e etc.

Nesse sentindo, faz-se necessário uma leitura do espaço e dos fenômenos de forma integrada. Entendendo, não somente os impactos, mas também os processos e efeitos que se consolidam a partir da efetivação do modelo de produção vigente de forma hegemônica e que conforme identificado pela pesquisa, cresce na microrregião de Ceres ao longo dos anos.

As imposições do modo de produção capitalista no espaço agrário promoveu a transformação do conservador latifúndio em modernas empresas rurais. No recorte estudado, observa-se que para além da concentração fundiária há o controle da terra, com a territorialização crescente do monocultivo em pauta. 
Entende-se então que o uso e a apropriação do Cerrado se intensificou com o processo de modernização da agricultura, que possui características conservadoras, já que não houve uma ruptura quanto à estrutura agrária. A permanência do camponês na terra, frente à isso, constitui-se como um desafio para esses sujeitos que não encontram o aporte do Estado na mesma proporção que o agronegócio se sustenta neste braço.

Os componentes naturais também são colocados em disputa injusta e apropriados de forma privada por atores hegemônicos que possuem estreita relação com o poder a partir por exemplo da chamada bancada ruralista. O Cerrado, nessa perspectiva, aparece como espaço estratégico para a expansão da fronteira agrícola.

É evidente, portanto, a necessidade de uma Reforma Agrária, coerente, pensada a partir dos biomas e seus povos e pela diversidade natural, social e etc. Historicamente, as políticas que incentivaram o uso e apropriação do Cerrado, priorizaram o médio e o grande proprietário, facilitando a venda de terras do Cerrado para grandes investidores do Sul, em contrapartida, os expropriados do Nordeste, aparecem como mão de obra barata, evidenciando a ineficiência dessas políticas no equilíbrio das desigualdades regionais.

Os incentivos criados pelo Estado, através da concessão de fomento e de condições favoráveis para a produção de commodities legitimam e impulsionam o processo de expansão da fronteira agrícola nas áreas de Cerrado. A ausência de fiscalização, ou os problemas quanto a ineficiência da existente, corroboram que essa realidade se propague deixando rastros de injustiças ambientais e sociais.

Os camponeses ilhados pelos monocultivos de cana, os cemitérios de árvores, o trabalho análogo ao escravo, as nascentes depredadas, o controle da renda da terra, a contaminação de solo, ar e água pelo uso de insumos, delineiam o quadro de verdadeira violência da territorialização do setor para o Cerrado. Setor esse que tem se resignificado ao longo dos anos.

\section{REFERÊNCIAS}

ARRAIS, T. A. A produção do território goiano: economia, urbanização, metropolização. Goiânia: Ed. UFG, 2013.

BEZERRA, J. E. Agronegócio e ideologia: contribuições teóricas. In: Revista NERA. Ano 12, n. 14. p. 112-124. Jan/Jun, 2009.

BORGES, R.E. No meio da soja, o brilho dos telhados: a implantação da perdigão em Rio Verde (GO), transformações e impactos socioeconômicos e espaciais. Rio Claro: UNESP, 2006.

BRASIL, Brasil bate mais um recorde na produção de cana-de-açúcar. In: Ministério da Agricultura Pecuária e Abastecimento. Notícia: 30/04/2009 -11:09. MAPA, $2009 . \quad$ Disponível em: <http://www.agricultura.gov.br/comunicacao/noticias/2009/04/brasil-bate-mais-umrecorde-na-producao-de-cana-de-acucar>. Acesso em: fev de 2016.

BRASIL, Brasil deve produzir safra recorde de cana-de-açucar na safra 2006/2007. In: Ministério da Agricultura Pecuária e Abastecimento. Notícia: 31/05/200615:58. 
$<$ http://www.agricultura.gov.br/comunicacao/noticias/2006/05/brasil-deve-produzirsafra-recorde-de-cana-de-acucar-na-safra-20062007>. Acesso em: fev de 2016.

BRASIL, Plano Nacional de Agroenergia 2006 - 2011. In: Ministério da Agricultura Pecuária e Abastecimento. $2^{\mathrm{a}} \mathrm{ed}$. Revisada. Embrapa Informação Tecnológica, Brasília, DF 2006.

CASTILHO, D. A Colônia Agrícola Nacional de Goiás (CANG) e a formação de Ceres- GO - Brasil. In: Élisée, Revista Geografia. UEG - Goiânia, v.1, n.1, p.117139, jan./jun. 2012.

CASTRO, S.S. Painel II: Expansão da cana-de-açúcar e os efeitos socioambientais nas áreas de Cerrado. In.: 10 Workshop sobre"A expansão da agroindústria canavieira em Goiás- Brasil; Efeitos socioambientais e precarização do trabalho no campo". Goiânia: Universidade Federal de Goiás, Instituto de Estudos Socioambientais: 09 dez 2013.

CHAVEIRO, E. F. CASTILHO,D. Por uma análise territorial do Cerrado. In: PELÁ, M. CASTILHO, D. (Org.). Cerrados: perspectivas e olhares. Goiânia: Vieira, 2010.

CHAVEIRO, E. F.; CASTILHO, D. Cerrado: patrimônio genético, cultural e simbólico. In: Revista Mirante, v. 2, n.1. Pires do Rio - GO: UEG, 2007.

DELGADO, G. C. Do capital financeiro na agricultura à economia do agronegócio: mudanças cíclicas em meio século (1965 - 2012). Porto Alegre, Editora da UFRGS, 2012.

DEUS, J.B.; Disciplina "Ambiente e apropriação da Região do Cerrado" do Programa de Pós-Graduação em Geografia da UFG, no dia 24 de novembro de 2015, no auditório do Instituto de Estudos Socioambientais da Universidade Federal de Goiás. Goiânia, 2015.

FERREIRA, L. C. G. DEUS, J. B. de. O uso do território e as redes na microrregião Ceres (GO): o caso das agroindústrias sucroalcooleiras. In: Boletim Goiano de Geografia. Goiânia, v. 30, n. 2, p. 67-80. 2010.

FERREIRA, L. C. G. A evolução do setor sucroalcooleiro na microrregião Ceres (GO): dinâmica espacial e impactos socioeconômicos. Goiânia, 2010.

FREITAS, R. L. CLEPS JÚNIOR, J. A territorialização do setor sucroenergético e o agrohidronegócio no triângulo mineiro/Alto Paranaíba. mundo do trabalho . In: Revista Pegada, v. 13 n.1 168 junho/2012.

GRAZIANO NETO, F. Questão Agrária e ecologia: Crítica da moderna agricultura. Brasiliense. São Paulo, 1982.

IBASE (Instituto Brasileiro de Análises Social e Econômicas) - A ocupação dos cerrados: Uma análise crítica. Setembro - 1986. 
KLINK, C. A. MACHADO, R. B. A conservação do Cerrado brasileiro. In: Megadiversidade, v.1, n.1, julho 2005. Disponível em: < http://www.equalisambiental.com.br/wpcontent/uploads/2013/02/Cerrado_conservacao.pdf> . Acesso em: fev de 2016.

MENDONÇA, M. R. A urdidura espacial do capital e do trabalho no Cerrado goiano: as tramas, as $(\mathrm{Re})$ Existências e a unicidade orgânica do trabalho. In: Agroecologia: práticas e saberes. (Org.) MENDONÇA, Marcelo Rodrigues. 2 ed. - Catalão: Gráfica modelo, 2012.

MENDONÇA, M. R. A urdidura espacial do capital e do trabalho no Cerrado do sudeste goiano. Presidente Prudente, 2004.

MOYSÉS, A. SILVA, E. R. da. Ocupação e urbanização dos cerrados: desafios para a sustentabilidade. In.: Cadernos Metrópole, 20 p. 197-220, 2008.

PELÁ, M. CASTILHO, D. Cerrados: perspectivas e olhares. Goiânia: Vieira, 2010.

PIRES, M. O. Programas agrícolas na ocupação do Cerrado. In: Sociedade e Cultura, v. 3, n. 1 e 2, jan/dez. 2000.

SILVA, E. B. ANJOS, A. F. O monitoramento do desmatamento e as ações de conservação do bioma Cerrado na primeira década do século XXI. In: PELLÁ, M. CASTILHO, D. (Org.). Cerrados: perspectivas e olhares. Goiânia: Vieira, 2010.

SILVA, W. F. A agroindústria canavieira em Goiás: a questão técnico-gerencial e as estratégias de controle fundiário. Instituto de Estudos Socioambientais, Universidade Federal de Goiás. Goiânia, 2016.

THOMAZ JÚNIOR, A. O agrohidronegócio no centro das disputas territoriais e de classe no Brasil do século XXI. In: Revista de Geografia Agrária, v.5, n.10, p. 92122, ago./2010. 